\title{
Antarctic Ice Shelves Lose Most of Their Mass From Shallow Depths

\author{
Ole Richter ${ }^{1,2}$, Benjamin K. Galton-Fenzi ${ }^{3}$, David E. Gwyther ${ }^{1}$, Kaitlin A. \\ Naughten $^{4}$, Matt A. King ${ }^{2}$ \\ ${ }^{1}$ Institute for Marine and Antarctic Studies, University of Tasmania, Private Bag 129, Hobart, TAS, 7001, \\ Australia. \\ ${ }^{2}$ Geography \& Spatial Sciences, School of Technology, Environments and Design, University of Tasmania, \\ Hobart, TAS, 7001, Australia. \\ ${ }^{3}$ Australian Antarctic Division, Kingston, TAS, 7050, Australia
} \\ ${ }^{4}$ British Antarctic Survey, High Cross, Madingley Road, Cambridge, CB3 0ET, United Kingdom.
}

This is a non-peer reviewed preprint submitted to EarthArXiv. This preprint has also been submitted to Geophysical Research Letters for peer review.

\section{Key Points:}

- High resolution ocean model highlights Antarctic ice shelf mass loss from shallow depths.

- Advection of solar heated surface waters plays a major role in driving Antarctic ice shelf melting.

- Future research into Antarctic ice sheet evolution should also focus on shallow ocean processes.

Corresponding author: Ole Richter, ole.richter@utas.edu.au 


\begin{abstract}
Understanding the processes involved in basal melting of Antarctic ice shelves is important to quantify the rate at which Antarctica will lose mass. Current research of of ice shelf-ocean interaction is almost exclusively guided by satellite derived estimates of Antarcticwide ice shelf melting, which highlight deep warm water intrusions and melting along ice shelf grounding lines. Here we analyse an estimate of Antarctic ice shelf melting derived from state-of-the-art ocean modelling. The model suggest that $79 \%$ (954 Gt/yr) of the total mass loss comes from ice shallower than $400 \mathrm{~m}$ deep. Melting at depths shallower than $200 \mathrm{~m}$ contributes 33 \% (399 Gt/yr) of the total mass loss and triples in summer, when solar heated surface waters advect under the ice. Thus, research should not just focus on deep warm water intrusions, but also the processes that control surface water advection and melting at shallow depths.
\end{abstract}

\title{
Plain Language Summary
}

Where Antarctic glaciers discharge into the Southern Ocean, ice streams go afloat and form ice shelves with water-filled cavities underneath. Warming oceans drive melting at the ice shelf base - understanding the details of this process is important to better predict future glacier retreat and related sea level rise. Monitoring the rate at which ice shelf melting occurs is difficult at large scales, due to the remoteness and harsh conditions of the Polar environment. Nevertheless, satellite data has been used to infer Antarcticwide ice shelf melting, highlighting ocean processes at depth. Here we use ocean modelling as an alternative tool to estimate Antarctic ice shelf melting. We find that a substantial part of the total mass loss in the model originates from the shallowest depths near the end of the ice streams, a region which satellite methods struggle to resolve. The model further suggests that solar heating of the surface ocean and the subsequent flow of this water under the ice front is responsible for much of the melting at these shallow depths. Future studies that aim to project Antarctic ice sheet retreat should not just focus on processes at depth, but should also account for changes in the upper ocean.

\section{Introduction}

Ice shelf basal melting and refreezing can change the thickness and stability of ice shelves, impacting the buttressing of inland ice sheets and slowing their discharge and therefore influencing sea level rise (Reese et al., 2018). Basal melting also impacts the salinity, temperature and circulation of the surrounding oceans with consequences for global ocean circulation and climate (Bronselaer et al., 2018; Golledge et al., 2019).

Studying ocean-ice shelf interaction at a continent scale is difficult, as only few direct observations exist. For Antarctic-wide estimates of ice shelf basal melting we currently rely almost exclusively on methods that use satellite data to infer basal melting as the missing component in a mass budget analysis (Rignot et al., 2013; Depoorter et al., 2013; Liu et al., 2015). The accuracy of these methods suffers from uncertainties in the satellite data itself, poor estimates of iceberg mass loss and the use of atmospheric models for near-surface firn processes. While ice shelf averages derived from budgets across ice shelf or ice flow line boundaries often agree within their uncertainties, high resolution results do not integrate to the same values and their uncertainty has not been quantified (see Richter et al., 2020, their Tab. A1).

Ocean models which include an ice shelf component have also been used to study Antarctic-wide ice shelf melting at high resolution (Hellmer, 2004; Losch, 2008; Timmermann et al., 2012; Naughten et al., 2018). However, these models often neglect important ocean dynamics, such as eddies and tides, and do not resolve many of the smaller ice shelves (Dinniman et al., 2016), leading to large biases in their quantitative results. Developing these models is important, because their estimates are independent from the 
uncertainties related to methods using satellite data (Schodlok et al., 2016), they resolve an ocean that is consistent with the melt rates, and they are ultimately used to predict past and future changes (Hellmer et al., 2012; Obase et al., 2017; Naughten et al., 2018).

The lack of independent estimates of Antarctic ice shelf melting hinders our understanding of the oceanic processes involved. Observations and models suggest that intrusions of warm deep water masses that cross the continental shelf break and reach the ice shelf cavities can explain the large scale differences in melting around Antarctica (Rignot et al., 2013; Pritchard et al., 2012), and hence many studies have focused on processes controlling the strength and depth of these intrusions (e.g. Kimura et al., 2017; Greene et al., 2017; A. L. Stewart et al., 2018; Davis et al., 2018; Hattermann, 2018). However, there is some evidence from regional studies that seasonal advection of solar heated surface waters can drive strong melting near the ice front (Horgan et al., 2011; Stern et al., 2013; Arzeno et al., 2014; Hattermann et al., 2012) or control the basal mass balance of entire ice shelves (Zhou et al., 2014; Hattermann et al., 2014; Joughin \& Padman, 2003). Notably, recent in situ observations from the Ross Ice Shelf suggest that surface waters from a nearby polynya drive melting at shallow depths at an order of magnitude higher rate than the shelf-wide average (C. L. Stewart et al., 2019).

A new estimate of Antarctic-wide ice shelf melting at high resolution has recently been derived from an ocean model with improved representations of important physics (Richter et al., 2020). Here we analyse these model results as well as a comparable estimate from satellite studies to quantify the mass loss distribution from different depth ranges and provide Antarctic-wide context for the role of surface water driven melting.

\section{Material and Methods}

\subsection{Model Description}

We analyse a prediction of Antarctic ice shelf melting during 2007 derived with the Whole Antarctic Ocean Model (WAOM v1.0). The simulation and its evaluation is described in detail elsewhere (Richter et al., 2020), here we outline only the technical details relevant for this study. Major improvements of WAOM compared to previous largescale models are the inclusion of tides and an eddy resolving resolution. Tidal currents have been shown to modulate ice shelf basal melting by enhancing the turbulence at the ice shelf base, as well as by increasing vertical mixing and interacting with mean circulation upstream (Padman et al., 2018). A high horizontal resolution is necessary to resolve critical shoreward heat transport by bathymetric troughs and eddies (A. L. Stewart et al., 2018; Nakayama et al., 2014) as well as the ocean circulation under small ice shelves around the continent (Hellmer, 2004; Timmermann et al., 2012). With $2 \mathrm{~km}$ resolution the simulation captures the critical amounts of eddy-driven heat flux across the shelf break, resolves more than 1.6 million $\mathrm{km}^{2}$ of ice (Fig. 1) and allows us to calculate mass loss quantities for 176 individual ice shelves (Table A1).

The vertical coordinate system of the model (terrain following) necessitates smoothing of the ice draft and this results in a representation of the ice front with a cavity inward sloping topography rather than a vertical cliff face. These modifications are likely to increase water mass exchange between the continental shelf and the sub-ice shelf cavity (Wåhlin et al., 2020). Recent observations, however, suggest that a smooth ice front mimics an underappreciated wedge mechanism: that is, melting along the submarine part of the vertical ice face tends to slope isopycnals under the ice front and provides a pathway for summer surfaces water inflow (Malyarenko et al., 2019). The model results support this idea, as simulated melt rates of the outermost cells compare well against in situ observations from the front of the north-western Ross Ice Shelf (up to $10 \mathrm{~m} / \mathrm{yr}$ just east of Ross Island; Arzeno et al., 2014; C. L. Stewart et al., 2019). 
A cold bias under some of the warm water ice shelves has been previously reported (Richter et al., 2020). Affected ice shelves are, e.g. Pine Island, Getz, Shackleton, and combined Totten and Moscow University. We note that these model deficiencies do not impact the conclusions of this study. For example, artificially increasing melt rates in high-melt areas, the Amundsen-Bellingshausen Seas, by a factor of two only changes the mass loss fraction of ice shallower than $400 \mathrm{~m}$ by $0.01 \%$.

\subsection{Satellite Estimates}

To confirm the importance of shallow ice mass loss, we compare our results against the depth distribution of previously published satellite estimates of ice shelf melting around Antarctica. At the time of writing, two high resolution products are available (Rignot et al., 2013; Adusumilli et al., 2020). Both estimates confirm the conclusions of this study and here we present results from the more established one (Rignot et al., 2013). To derive the total mass loss and depth distribution of the published data, we interpolated the melt rates as well as ice shelf masks onto the model grid and used ice draft data from Bedmap2 (Fretwell et al., 2013). The MEaSURES ice shelf boundaries (Mouginot et al., 2016) have been used to calculate mass loss of individual ice shelves.

\section{The Shallow Ice Contribution}

The simulation results suggest that $79 \%(954 \mathrm{Gt} / \mathrm{yr})$ of the Antarctic ice shelf basal mass loss $(1207 \mathrm{Gt} / \mathrm{yr})$ comes from ice that is shallower than $400 \mathrm{~m}$ as shown in Figure 1 and Figure 2. Even though the model predicts the highest melt rates at the greatest depths (on average $5.2 \mathrm{~m} / \mathrm{yr}$ from $2200 \mathrm{~m}$ to $2300 \mathrm{~m}$ ), such deep ice only exists in a few regions (such as near the grounding lines of the Filchner-Ronne, Ross, and Amery Ice Shelves) and hence its area-integrated contribution to the total mass loss is relatively small. Between 200 and $400 \mathrm{~m}$ depth, melt rates are moderate $(0.8 \mathrm{~m} / \mathrm{yr})$, but since almost half of the ice shelf drafts occur between these depths (48\%), mass loss integrates to its largest contribution (46\%). Towards the ice front (200 $\mathrm{m}$ and shallower) melting increases (up to $1.9 \mathrm{~m} / \mathrm{yr}$ for the shallowest $100 \mathrm{~m}$ ) and a relatively small area $(17 \%$ ) integrates to a large mass loss contribution (33\%). Melting from ice shallower than $400 \mathrm{~m}$ is the dominant source of ice shelf basal mass loss in all individual Antarctic regions with ice shallower than $200 \mathrm{~m}$ alone making up substantial amounts (Table A1).

The depth distribution of Antarctic ice shelf melting derived from satellite methods (Rignot et al., 2013) confirms the importance of shallow ice (see Sect. 2.2, Fig. 2).Those results suggest that $48 \%$ (494 Gt/yr) of the total mass loss (1046 Gt/yr) comes from ice that is shallower than $400 \mathrm{~m}$, despite up to ten times higher melting at greater depths (up to $11.8 \mathrm{~m} / \mathrm{yr}$ for the $2000 \mathrm{~m}$ to $2100 \mathrm{~m}$ depth bin). Most of the difference in shallow mass loss fraction between the model and the data originates from depths shallower than $200 \mathrm{~m}$ (only $12 \%, 127 \mathrm{Gt} / \mathrm{yr}$, of the total mass loss). A large fraction of this ice coincides with the ice shelf front (e.g. the ice shelves outermost $6 \mathrm{~km}$ comprise $41 \%$ of the ice shallower than $200 \mathrm{~m}$ deep). Sampling dynamic ice shelf fronts is difficult using low spatial and temporal resolution satellite data, meaning they may not fully represent change in these regions. For instance, calving events during the sampling periods require boundaries several $\mathrm{km}$ away from the actual termini of the ice shelves, leaving ice shelf melting close to the front unresolved (Liu et al., 2015). Recent in situ observations, however, highlight enhanced melting below this part of the world's largest ice shelf, the Ross Ice Shelf, with melt rates up to an order of magnitude higher than the shelf average (C. L. Stewart et al., 2019). 


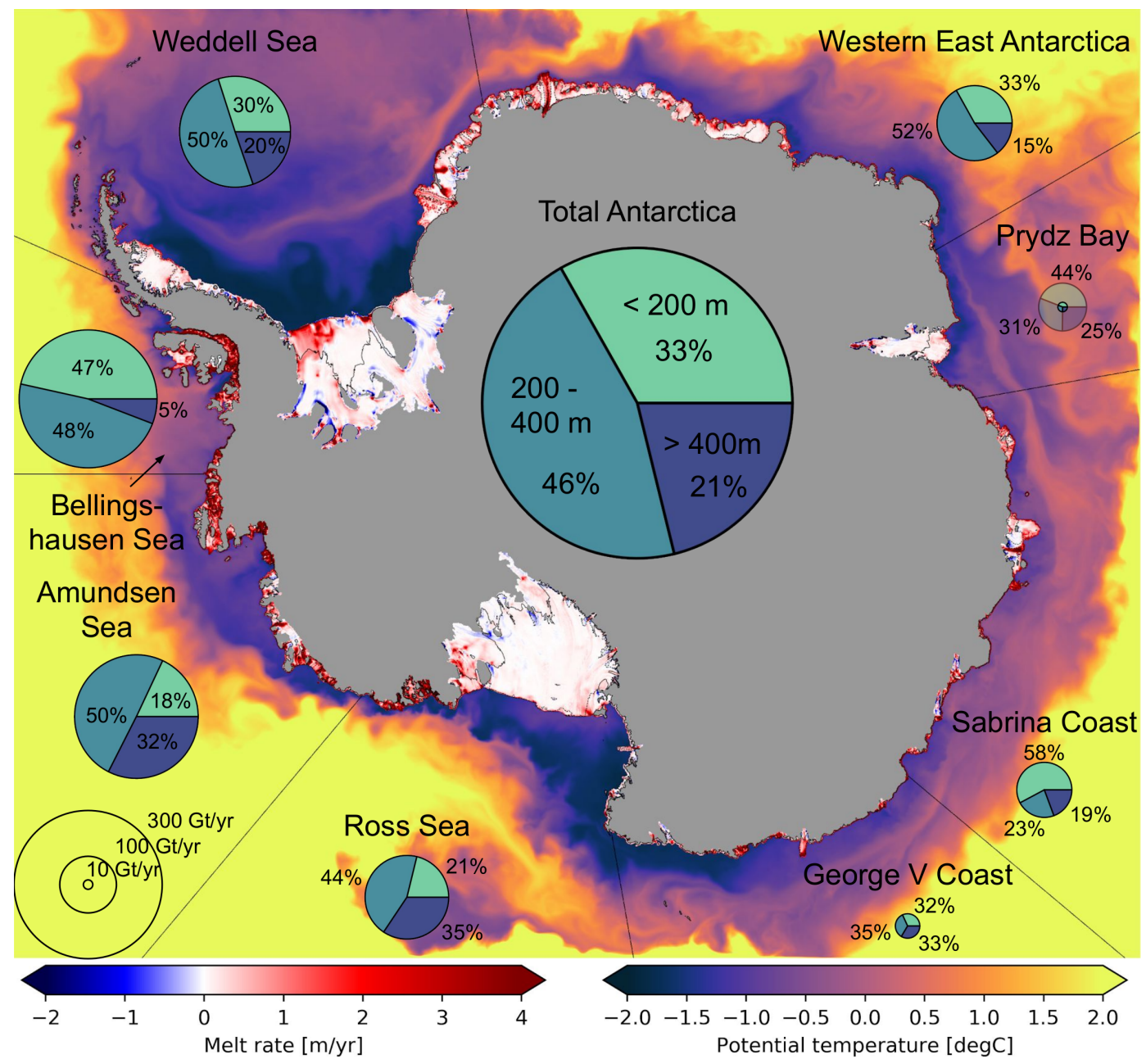

Figure 1. Ice shelf basal melting and surface ocean temperature around Antarctica derived from ocean modelling (Richter et al., 2020). Seaward of ice shelves, 2007 average potential temperature of the surface ocean (uppermost sigma layer). Within ice shelves, 2007 average basal melt rate. Solid and dashed lines indicate $400 \mathrm{~m}$ and $200 \mathrm{~m}$ ice draft, respectively. Pie chart areas are proportional to the mass loss from each sector, in Gt/yr. Pie chart partitions indicate mass loss integrated over depth ranges (shallower than $200 \mathrm{~m}$, between $200 \mathrm{~m}$ and $400 \mathrm{~m}$, deeper than $400 \mathrm{~m}$ ). Total Antarctica and Prydz Bay pie charts have been scaled for ease of readability. B. Sea is short for Bellingshausen Sea. Basal melting shallower than $400 \mathrm{~m}$ is the dominant source of mass loss in all regions with ocean temperatures indicating the role of surface processes. 

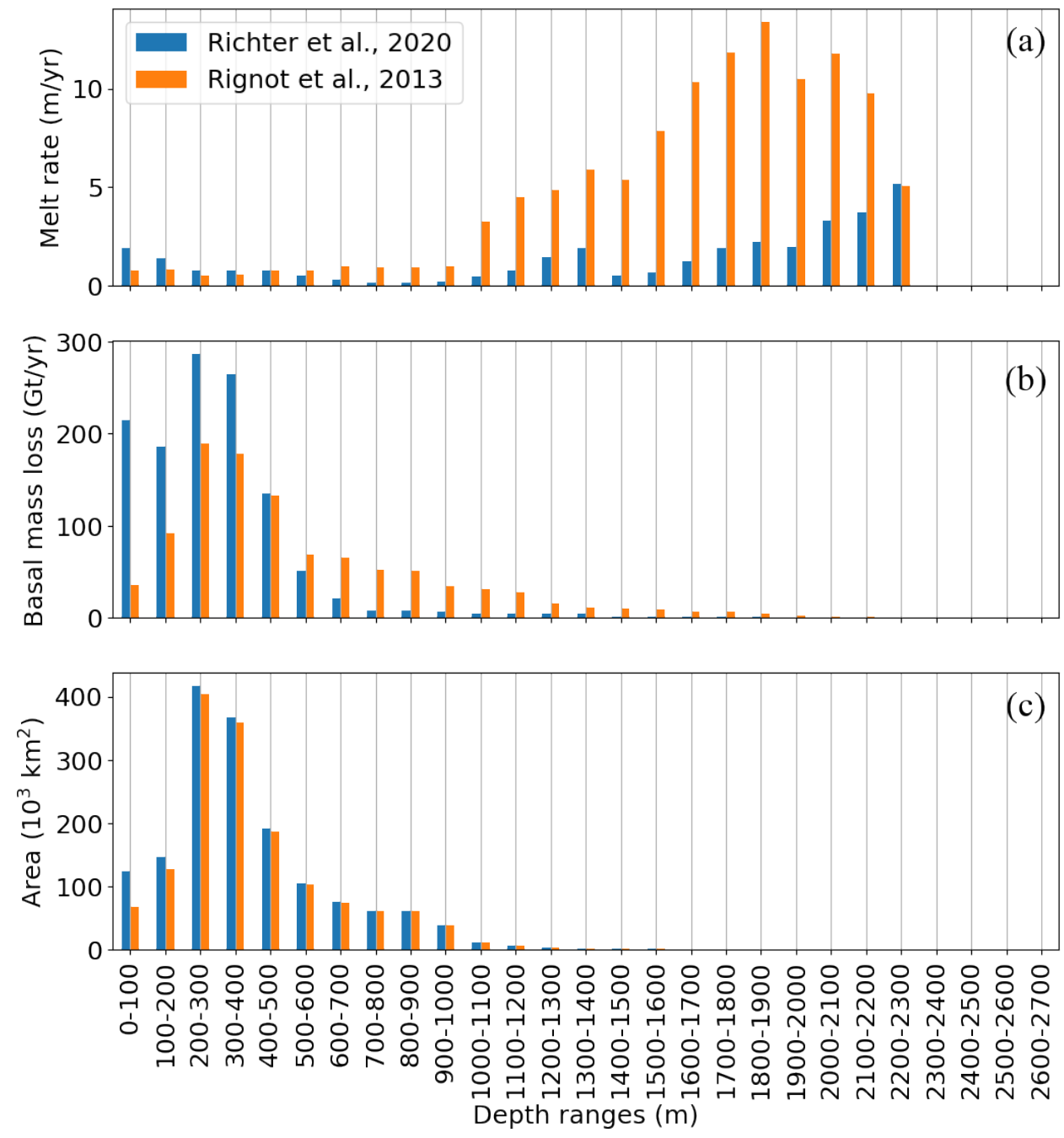

Figure 2. Ice shelf basal melt rates, mass loss and area at different depths from ocean modelling (Richter et al., 2020) and satellite observations (Rignot et al., 2013). (a) Ice shelf melting averaged over $100 \mathrm{~m}$ depth ranges. (b) Integrated mass loss. (c) Integrated area of ice shelf draft. (b) and (c) have been calculated using Bedmap2 ice draft data (Fretwell et al., 2013). Moderate melt rates at shallow depths integrate to highest mass loss contributions, due to large available area. 


\section{The Surface Ocean as Driver of Change}

The model results suggest that advection of solar heated surface waters is an important driver of shallow ice melting. The surface ocean adjacent to the ice is often significantly warmer than the freezing point (Fig. 1). Solar radiation heats the surface of the Southern Ocean to more than $10{ }^{\circ} \mathrm{C}$ above freezing in summer, but on the Antarctic continental shelf, Antarctic Surface Water (AASW) is cooled by a thick sea ice cover in winter and glacial melt water all through the year. Warm streams from offshore are brought towards and around the coast by barotropic large-scale circulation, such as the Weddell Gyre or the Antarctic coastal current. Eddies can mix warm water shoreward or upwell heat from greater depth, as apparent in the Bellingshausen Seas, while sea ice polynyas open a pathway for solar heating close to coast even in winter, e.g. near the Ross Ice Shelf front (C. L. Stewart et al., 2019). In our simulation, all these effects combined result in an upper continental shelf ocean (first $100 \mathrm{~m}$ ) with a mean temperature of $-1.1^{\circ} \mathrm{C}\left(0.75^{\circ} \mathrm{C}\right.$ above the surface freezing point $)$.

That warm AASW is indeed advecting under the ice front and reaches the shallow parts of many ice shelves is indicated by the temperature-salinity distribution of water inside the ice shelf cavities as shown in Figure 3. AASW typically has temperatures above freezing point and potential densities below $27.6 \mathrm{~kg} \mathrm{~m}^{-3}$. Similar characteristics, however, can arise when warmer and denser Modified Circumpolar Deep Water (MCDW) mix with fresh and cold melt water. The mixing process is visible in the temperaturesalinity space as lines with characteristic slope (Gade lines; Gade, 1979) and, thus, the absence of these lines indicates surface water origin for an ambiguous sample point. Following this argument, we identify AASW up to $200 \mathrm{~m}$ deep in western East Antarctica, Prydz Bay, the Weddell Sea, and the Sabrina and George V Coasts. While AASW could also be present at greater depths or in the ice shelf cavities of the other regions, we can not clearly trace the water mass origins using standard water mass characteristics analysis.

The extent to which surface water advection controls melt rates of shallow ice becomes evident by comparing the seasonal cycle in melt rates from different depths (Fig. 4). During Southern Hemisphere winter and spring (June to December) melt rates at all depths are relatively constant. In summer, however, melting of ice shallower than $200 \mathrm{~m}$ increases on average by $2.5 \mathrm{~m} / \mathrm{yr}(200 \%)$, with regional differences ranging from $1.5 \mathrm{~m} / \mathrm{yr}$ $(75 \%)$ in the Bellingshausen Sea up to $7 \mathrm{~m} / \mathrm{yr}$ (over $1000 \%$ ) in Prydz Bay, Sabrina Coast and George V Coast, while melt rates of deeper ice do not increase much above winter values. This distinct seasonal cycle is closely correlated to the surface ocean temperature of the adjacent continental shelf, suggesting that a fast heat transfer mechanism, such as advection, is at play. In western East Antarctica, the Amundsen Sea, and along the Sabrina and George V Coasts, deep ocean temperatures and melt rates show signs of this seasonal variation, indicating the influence of surface processes even below $200 \mathrm{~m}$ depth.

In situ observations confirm the importance of surface water driven melting at some locations around Antarctica. The idea of melt driven by warm surface water intrusions under the ice shelf frontal zone, also known as "Mode 3" melting, has been known for decades (Jacobs et al., 1992) and confirmed by in situ observations (Stern et al., 2013; Arzeno et al., 2014; Hattermann et al., 2012; C. L. Stewart et al., 2019; Malyarenko et al., 2019) and high resolution satellite data (Horgan et al., 2011). Our results suggest that surface waters drive melting all around Antarctica, causing a substantial contribution to the total mass loss.

Surface water driven melting is likely affected by small scale coastal processes, subject to respond to perturbations on rapid timescales and offering different feedback mechanisms than processes at depth. Global atmospheric warming is likely to directly increase upper ocean temperatures (Durack et al., 2018), but seasonal sea ice cover controls the 

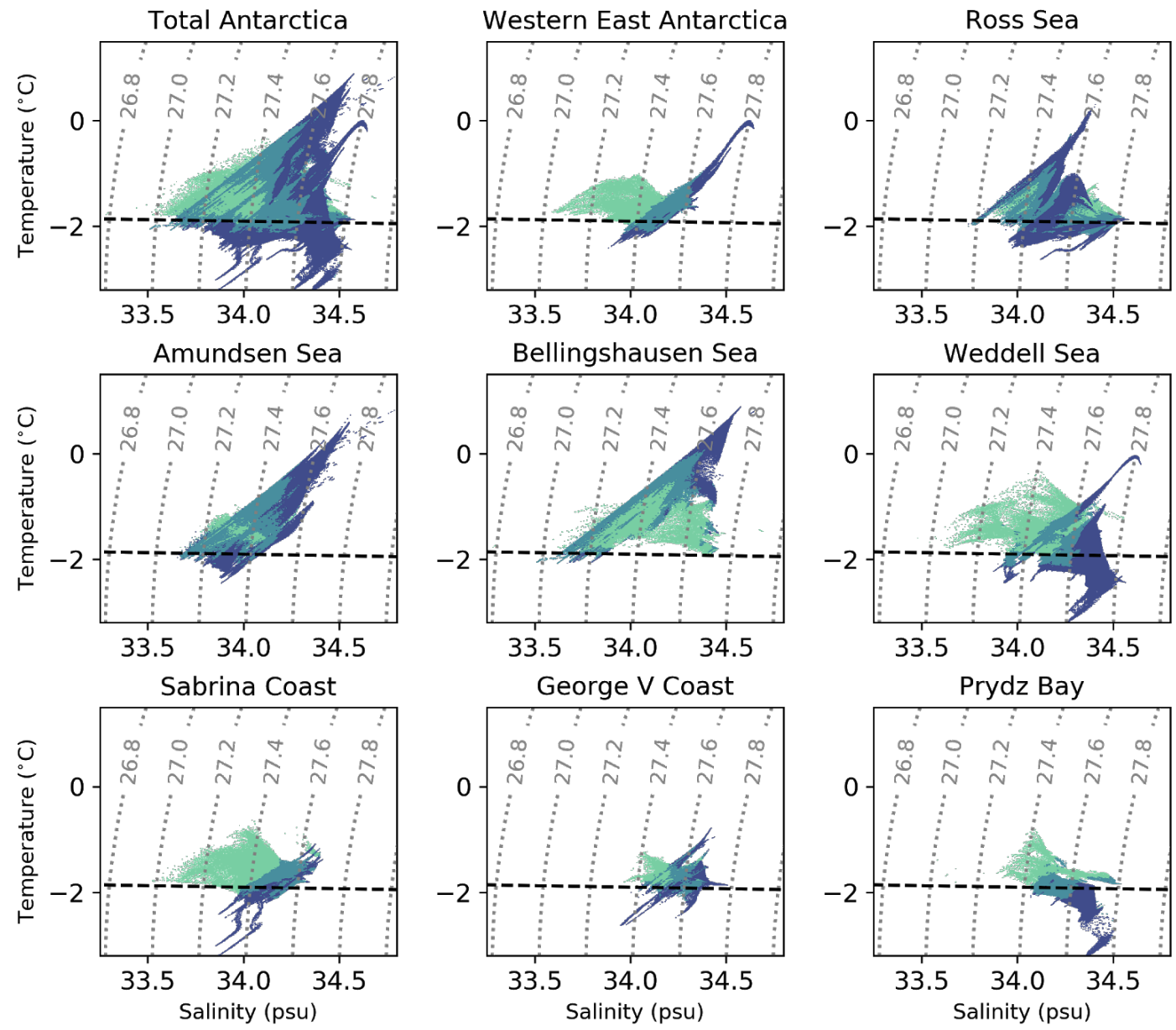

$$
<200 \mathrm{~m} \quad 200-400 \mathrm{~m} \quad>400 \mathrm{~m}
$$

Figure 3. Water masses present below the ice shelves. Potential Temperature-Salinity distribution of the ocean inside the ice shelf cavities for total Antarctica and each individual sector. Each grid box is sorted into 1000x1000 temperature and salinity bins and coloured based on depth. The surface freezing point is indicated by a dashed black line, and potential density contours $\left(\mathrm{kg} \mathrm{m}^{-3}\right)$ by dashed gray lines. 

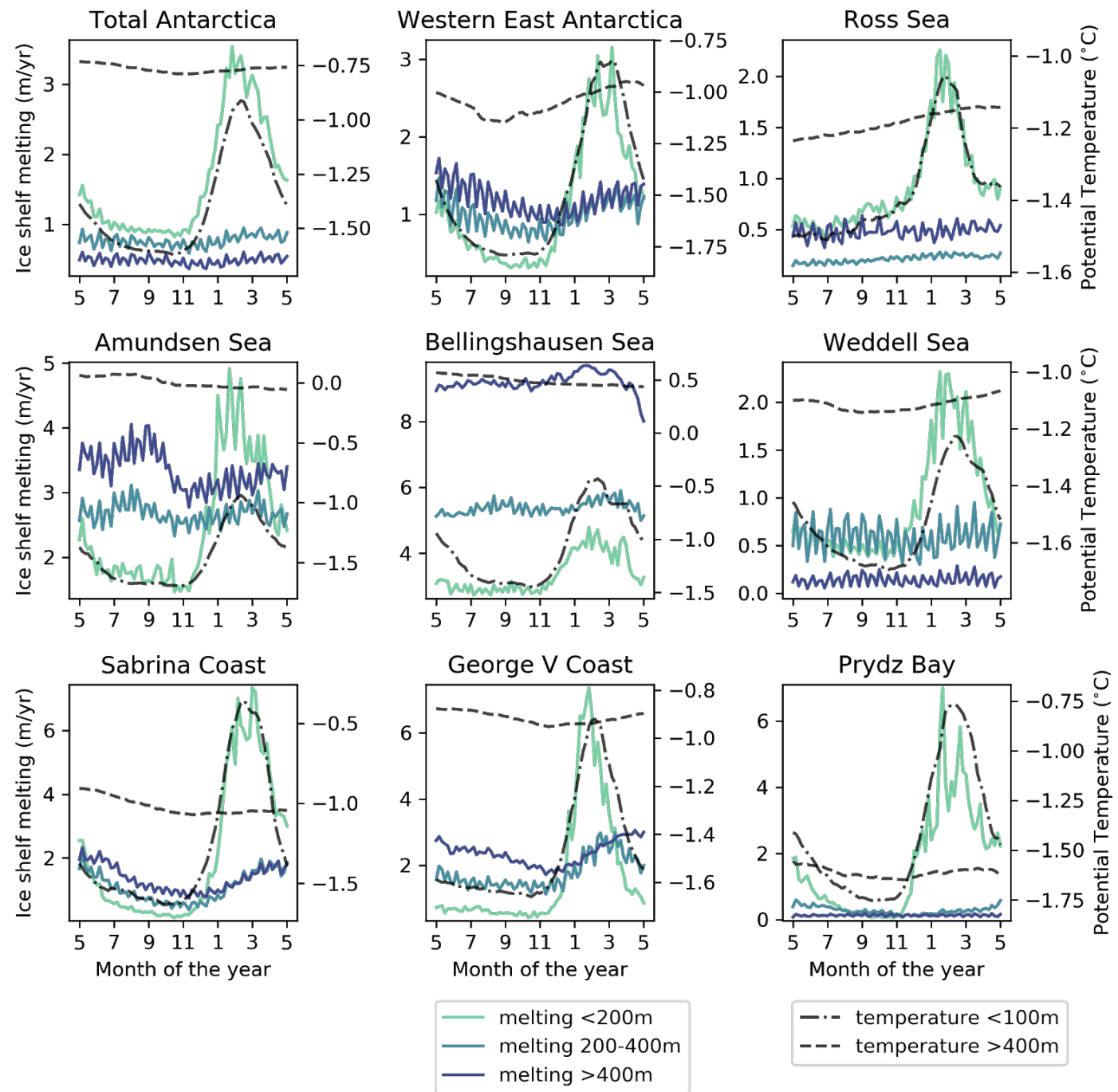

Figure 4. Relationship between ice shelf melting at different depths and adjacent surface and deep ocean temperature. Potential temperature is volume averaged over the continental shelf, above $100 \mathrm{~m}$ as well as below $400 \mathrm{~m}$. The continental shelf is defined using the $1000 \mathrm{~m}$ isobath and excluding ice shelf cavities. Ice shelf melting is area averaged for ice shallower than $200 \mathrm{~m}$, between $200 \mathrm{~m}$ and $400 \mathrm{~m}$, and deeper than $400 \mathrm{~m}$. Both are 5 day means and shown for total Antarctica and each individual sector. 
exposure to solar radiation and can change dramatically over yearly timescales (Parkinson, 2019). Further, easterly winds close to Antarctica are predicted to gain strength (Kushner et al., 2001) and the associated shoreward Ekman transport might cause enhanced AASW downwelling at the ice front (Zhou et al., 2014; Sverdrup, 1954). How changes in seasonal ice cover will impact the mean wind stress imported into the ocean is not well understood (Lüpkes \& Birnbaum, 2005). Finally, ice shelf thinning or large break up events do not just expose further inland ice to the surface ocean, but the consequent change in water column thickness also affects local tides (Mueller et al., 2018), which have often been suggested as one of the main drivers of water mass exchange across the ice front (Jacobs et al., 1992; Makinson \& Nicholls, 1999; MacAyeal, 1985). Seasonal sea ice, coastal winds and ice shelf geometry can change on short time-scales and its effects on surface water driven melting provide the means for a very dynamic response of shallow ice mass loss to climate change.

\section{Conclusion}

We have examined the outputs of a state-of-the-art ocean model and previously published satellite data to determine the depth distribution of Antarctic ice shelf melting. We find that both data sets highlight the mass loss contribution from shallow ice ( $<400 \mathrm{~m}$ deep). Towards the ice shelf front (often $<200 \mathrm{~m}$ deep), however, modelled melt rates are substantially higher than the satellite estimate suggests. Further, we identify advection of solar heated surface waters as playing a major role in melting of shallow ice melting in the model.

These findings challenge the current direction of research into Antarctic mass loss. Recent studies have focused on warm water intrusions in the deep ocean and melting along ice shelf grounding lines, but the modelling results and analysis presented here suggest that shallower processes also play a fundamental role. Not resolving these processes in models used to predict future climate might have far reaching consequences. The amount and depth at which glacial melt water is injected into the ocean impacts local water mass transformation with consequences for global ocean circulation and climate (Bronselaer et al., 2018; Golledge et al., 2019). The role of shallow ice melting for ice sheet dynamics are less clear. Integrating the instantaneous buttressing flux response for all ice shelf parts shallower than $400 \mathrm{~m}$ results in $34 \%$ of the response of deeper ice (Reese et al., 2018). Over decadal time scales, however, melting at shallow depths might precondition calving (Padman et al., 2012) and, at many places close to lateral boundaries or pinning points, ice shelves will undergo structural changes with even little ice front retreat (Fürst et al., 2016). To quantify these longer term effects, fully coupled ocean-ice sheet models will ultimately be needed.

\section{Acknowledgments}

The data underlying the figures of this study is available at https://data.utas .edu.au/metadata/ee816dd3-379a-489a-b78f-3dc1b16e0bef. The python code used to perform the analysis are archived at http://doi.org/10.5281/zenodo.3738998 (Richter, 2020) and the maintained version of these scripts is publicly available at https://github .com/kuechenrole/antarctic_melting.

This research was supported by scholarships from the Australian Government and the Australian Research Council's Special Research Initiative for the Antarctic Gateway Partnership SRI40300001. We would like to thank Eric Rignot, Jeremie Mouginot, Susheel Adusumilli and Helen Fricker for providing us with the satellite derived melt rates. We are also grateful to Ronja Reese for sharing the ice shelf buttressing flux response numbers with us and Richard Coleman for providing valuable comments on the manuscript. 


\section{References}

Adusumilli, S., Fricker, H. A., Medley, B. C., Padman, L., \& Siegfried, M. R. (2020). Data from: Ocean-driven melting of Antarctica's ice shelves varies on multi-year timescales. UC San Diego Library Digital Collections. Retrieved 2020-06-08, from http://library.ucsd.edu/dc/object/bb0448974g doi: 10.6075/J04Q7SHT

Arzeno, I. B., Beardsley, R. C., Limeburner, R., Owens, B., Padman, L., Springer, S. R., ... Williams, M. J. M. (2014, July). Ocean variability contributing to basal melt rate near the ice front of Ross Ice Shelf, Antarctica. Journal of Geophysical Research: Oceans, 119(7), 4214-4233. Retrieved 2018-1203, from https://agupubs.onlinelibrary.wiley.com/doi/abs/10.1002/ 2014JC009792 doi: 10.1002/2014JC009792

Bronselaer, B., Winton, M., Griffies, S. M., Hurlin, W. J., Rodgers, K. B., Sergienko, O. V., ... Russell, J. L. (2018, December). Change in future climate due to Antarctic meltwater. Nature, 564(7734), $53 . \quad$ Retrieved 2019-0108, from https://www.nature.com/articles/s41586-018-0712-z doi: 10.1038/s41586-018-0712-z

Davis, P. E. D., Jenkins, A., Nicholls, K. W., Brennan, P. V., Abrahamsen, E. P., Heywood, K. J., ... Kim, T.-W. (2018, November). Variability in Basal Melting Beneath Pine Island Ice Shelf on Weekly to Monthly Timescales. Journal of Geophysical Research: Oceans, 123(11), 8655-8669. Retrieved 2018-1230, from https://agupubs.onlinelibrary.wiley.com/doi/abs/10.1029/ 2018JC014464 doi: 10.1029/2018JC014464

Depoorter, M. A., Bamber, J. L., Griggs, J. A., Lenaerts, J. T. M., Ligtenberg, S. R. M., van den Broeke, M. R., \& Moholdt, G. (2013, October). Calving fluxes and basal melt rates of Antarctic ice shelves. Nature, 502(7469), 89-92. Retrieved 2018-12-03, from https: //www . nature.com/articles/nature12567 doi: $10.1038 /$ nature12567

Dinniman, M. S., Asay-Davis, X. S., Galton-Fenzi, B. K., Holland, P. R., Jenkins, A., \& Timmermann, R. (2016, December). Modeling Ice Shelf/Ocean Interaction in Antarctica: A Review. Oceanography, 29(4), 144-153. Retrieved 2018-12-03, from https://tos.org/oceanography/article/ modeling-ice-shelf-ocean-interaction-in-antarctica-a-review doi: 10.5670/oceanog.2016.106

Durack, P., Gleckler, P., Purkey, S., Johnson, G., Lyman, J., \& Boywe, T. (2018, June). Ocean Warming: From the Surface to the Deep in Observations and Models. Oceanography, 31(2), 41-51. Retrieved 2019-05-07, from https:// tos.org/oceanography/article/ocean-warming-from-the-surface-to-the -deep-in-observations-and-models doi: 10.5670/oceanog.2018.227

Fretwell, P., Pritchard, H. D., Vaughan, D. G., Bamber, J. L., Barrand, N. E., Bell, R., ... Zirizzotti, A. (2013, February). Bedmap2: improved ice bed, surface and thickness datasets for Antarctica. The Cryosphere, 7(1), 375-393. Retrieved 2018-12-03, from https://www.the-cryosphere.net/7/375/2013/ doi: https://doi.org/10.5194/tc-7-375-2013

Fürst, J. J., Durand, G., Gillet-Chaulet, F., Tavard, L., Rankl, M., Braun, M., \& Gagliardini, O. (2016, May). The safety band of Antarctic ice shelves. $\quad \mathrm{Na}$ ture Climate Change, 6(5), 479-482. Retrieved 2018-12-03, from http:// www.nature.com/articles/nclimate2912 doi: 10.1038/nclimate2912

Gade, H. G. (1979, January). Melting of Ice in Sea Water: A Primitive Model with Application to the Antarctic Ice Shelf and Icebergs. http://dx.doi.org/10.1175/1520-0485(1979)009<0189:MOIISW>2.0.CO;2. Retrieved 2019-05-09, from https://journals.ametsoc.org/doi/abs/10.1175/ 1520-0485\%281979\%29009\%3C0189\%3AMOIISW\%3E2.0.CO\%3B2

Golledge, N. R., Keller, E. D., Gomez, N., Naughten, K. A., Bernales, J., Trusel, L. D., \& Edwards, T. L. (2019, February). Global environmental consequences 
of twenty-first-century ice-sheet melt. Nature, 566(7742), 65. Retrieved 201907-16, from https://www.nature.com/articles/s41586-019-0889-9 doi: 10.1038/s41586-019-0889-9

Greene, C. A., Blankenship, D. D., Gwyther, D. E., Silvano, A., \& Wijk, E. v. (2017, November). Wind causes Totten Ice Shelf melt and acceleration. Science Advances, 3(11). Retrieved 2018-12-03, from http://advances.sciencemag . org/content/3/11/e1701681 doi: 10.1126/sciadv.1701681

Hattermann, T. (2018, September). Antarctic Thermocline Dynamics along a Narrow Shelf with Easterly Winds. Journal of Physical Oceanography, 48(10), 2419-2443. Retrieved 2018-12-03, from https://journals.ametsoc.org/doi/ full/10.1175/JPO-D-18-0064.1 doi: 10.1175/JPO-D-18-0064.1

Hattermann, T., Nøst, O. A., Lilly, J. M., \& Smedsrud, L. H. $\quad$ (2012). $\quad$ Two years of oceanic observations below the Fimbul Ice Shelf, Antarctica. Geophysical Research Letters, 39(12). Retrieved 2019-05-10, from https:// agupubs.onlinelibrary.wiley.com/doi/abs/10.1029/2012GL051012 doi: 10.1029/2012GL051012

Hattermann, T., Smedsrud, L. H., Nøst, O. A., Lilly, J. M., \& Galton-Fenzi, B. K. (2014, October). Eddy-resolving simulations of the Fimbul Ice Shelf cavity circulation: Basal melting and exchange with open ocean. Ocean Modelling, 82, 28-44. Retrieved 2018-12-04, from http://www.sciencedirect.com/science/ article/pii/S1463500314000948 doi: 10.1016/j.ocemod.2014.07.004

Hellmer, H. H. (2004, May). Impact of Antarctic ice shelf basal melting on sea ice and deep ocean properties. Geophysical Research Letters, 31(10). Retrieved 2018-12-03, from https://agupubs.onlinelibrary.wiley.com/doi/abs/ 10.1029/2004GL019506 doi: 10.1029/2004GL019506

Hellmer, H. H., Kauker, F., Timmermann, R., Determann, J., \& Rae, J. $\quad$ (2012, May). Twenty-first-century warming of a large Antarctic ice-shelf cavity by a redirected coastal current. Nature, 485(7397), 225-228. Retrieved 2019-02-01, from https://www. nature.com/articles/nature11064 doi: $10.1038 /$ nature11064

Horgan, H. J., Walker, R. T., Anandakrishnan, S., \& Alley, R. B. (2011, February). Surface elevation changes at the front of the Ross Ice Shelf: Implications for basal melting. Journal of Geophysical Research: Oceans, 116(C2). Retrieved 2019-02-26, from https://agupubs.onlinelibrary.wiley.com/doi/abs/ 10.1029/2010JC006192 doi: 10.1029/2010JC006192

Jacobs, S. S., Helmer, H. H., Doake, C. S. M., Jenkins, A., \& Frolich, R. M. (1992). Melting of ice shelves and the mass balance of Antarctica. Journal of Glaciology, 38(130), 375-387. Retrieved 2019-05-10, from https:// www. cambridge.org/core/journals/journal-of-glaciology/article/ melting-of-ice-shelves-and-the-mass-balance-of-antarctica/ B4841D1BF7AD77C197F8FDA33BE9936C doi: 10.3189/S0022143000002252

Joughin, I., \& Padman, L. (2003, May). Melting and freezing beneath FilchnerRonne Ice Shelf, Antarctica. Geophysical Research Letters, 30(9). Retrieved 2018-12-03, from https://agupubs.onlinelibrary.wiley.com/doi/abs/ 10.1029/2003GL016941 doi: 10.1029/2003GL016941

Kimura, S., Jenkins, A., Regan, H., Holland, P. R., Assmann, K. M., Whitt, D. B., ... Dutrieux, P. (2017). Oceanographic Controls on the Variability of Ice-Shelf Basal Melting and Circulation of Glacial Meltwater in the Amundsen Sea Embayment, Antarctica. Journal of Geophysical Research: Oceans, 122(12), 10131-10155. Retrieved 2018-12-25, from https:// agupubs onlinelibrary .wiley . com/doi/abs/10.1002/2017JC012926 doi: 10.1002/2017JC012926

Kushner, P. J., Held, I. M., \& Delworth, T. L. (2001, May). Southern Hemisphere Atmospheric Circulation Response to Global Warming. Journal of Climate, 14(10), 2238-2249. Retrieved 2019-05-09, from https://journals.ametsoc 
. org/doi/full/10.1175/1520-0442\%282001\%29014\%3C0001\%3ASHACRT $\% 3 E 2.0$ . CO\%3B2 doi: 10.1175/1520-0442(2001)014<0001:SHACRT $\rangle 2.0 . C O ; 2$

Liu, Y., Moore, J. C., Cheng, X., Gladstone, R. M., Bassis, J. N., Liu, H., ... Hui, F. (2015, March). Ocean-driven thinning enhances iceberg calving and retreat of Antarctic ice shelves. Proceedings of the National Academy of Sciences, 112(11), 3263-3268. Retrieved 2018-12-03, from http://www.pnas.org/ content/112/11/3263 doi: 10.1073/pnas.1415137112

Losch, M. (2008, August). Modeling ice shelf cavities in a z coordinate ocean general circulation model. Journal of Geophysical Research: Oceans, 113(C8). Retrieved 2018-12-04, from https://agupubs.onlinelibrary.wiley.com/doi/ abs/10.1029/2007JC004368 doi: 10.1029/2007JC004368

Lüpkes, C., \& Birnbaum, G. (2005, November). 'Surface Drag in the Arctic Marginal Sea-ice Zone: A Comparison of Different Parameterisation Concepts'. Boundary-Layer Meteorology, 117(2), 179-211. Retrieved 2019-02-06, from https://link. springer.com/article/10.1007/s10546-005-1445-8 doi: $10.1007 / \mathrm{s} 10546-005-1445-8$

MacAyeal, D. R. (1985, January). Tidal Rectification Below the Ross Ice Shelf, Antarctica. Oceanology of the Antarctic Continental Shelf. Retrieved 201905-10, from https://agupubs .onlinelibrary.wiley.com/doi/10.1029/ AR043p0109

Makinson, K., \& Nicholls, K. W. (1999). Modeling tidal currents beneath FilchnerRonne Ice Shelf and on the adjacent continental shelf: Their effect on mixing and transport. Journal of Geophysical Research: Oceans, 104(C6), 1344913465. Retrieved 2019-03-08, from https://agupubs.onlinelibrary.wiley .com/doi/abs/10.1029/1999JC900008 doi: 10.1029/1999JC900008

Malyarenko, A., Robinson, N. J., Williams, M. J. M., \& Langhorne, P. J. (2019). A Wedge Mechanism for Summer Surface Water Inflow Into the Ross Ice Shelf Cavity. Journal of Geophysical Research: Oceans, 124(2), 1196-1214. Retrieved 2019-09-11, from https://agupubs.onlinelibrary.wiley.com/doi/ abs/10.1029/2018JC014594 doi: 10.1029/2018JC014594

Mouginot, J., Rignot, E., \& Scheuchl, B. (2016). MEaSURES Antarctic Boundaries for IPY 2007-2009 from Satellite Radar, Version 1. Shelves. Boulder, Colorado USA: NASA National Snow and Ice Data Center Distributed Active Archive Center. Retrieved from http://dx.doi.org/10.5067/SEVV4MR8P1ZN.

Mueller, R. D., Hattermann, T., Howard, S. L., \& Padman, L. $\quad$ (2018, February). Tidal influences on a future evolution of the Filchner-Ronne Ice Shelf cavity in the Weddell Sea, Antarctica. The Cryosphere, 12(2), 453-476. Retrieved 2018-12-04, from https://www.the-cryosphere.net/12/453/2018/ doi: https://doi.org/10.5194/tc-12-453-2018

Nakayama, Y., Timmermann, R., Schröder, M., \& Hellmer, H. H. ～～２014, December). On the difficulty of modeling Circumpolar Deep Water intrusions onto the Amundsen Sea continental shelf. Ocean Modelling, 84, 26-34. Retrieved 2018-12-03, from https://linkinghub.elsevier.com/retrieve/pii/ S1463500314001383 doi: 10.1016/j.ocemod.2014.09.007

Naughten, K. A., Meissner, K. J., Galton-Fenzi, B. K., England, M. H., Timmermann, R., \& Hellmer, H. H. (2018, April). Future Projections of Antarctic Ice Shelf Melting Based on CMIP5 Scenarios. Journal of Climate, 31 (13), 5243-5261. Retrieved 2019-09-11, from https://journals.ametsoc.org/doi/ 10.1175/JCLI-D-17-0854.1 doi: 10.1175/JCLI-D-17-0854.1

Naughten, K. A., Meissner, K. J., Galton-Fenzi, B. K., England, M. H., Timmermann, R., Hellmer, H. H., .. Debernard, J. B. (2018, April). Intercomparison of Antarctic ice-shelf, ocean, and sea-ice interactions simulated by MetROMSiceshelf and FESOM 1.4. Geoscientific Model Development, 11(4), 1257-1292. Retrieved 2019-09-11, from https://www.geosci-model-dev.net/11/1257/ 2018/ doi: https://doi.org/10.5194/gmd-11-1257-2018 
Obase, T., Abe-Ouchi, A., Kusahara, K., Hasumi, H., \& Ohgaito, R.

$(2017$, February). Responses of Basal Melting of Antarctic Ice Shelves to the Climatic Forcing of the Last Glacial Maximum and CO2 Doubling. Journal of Climate, 30(10), 3473-3497. Retrieved 2018-12-03, from https:// journals . ametsoc.org/doi/full/10.1175/JCLI-D-15-0908.1 doi: 10.1175/JCLI-D-15-0908.1

Padman, L., Costa, D. P., Dinniman, M. S., Fricker, H. A., Goebel, M. E., Huckstadt, L. A., ... Broeke, M. R. v. d. (2012, January). Oceanic controls on the mass balance of Wilkins Ice Shelf, Antarctica. Journal of Geophysical Research: Oceans, 117(C1). Retrieved 2018-12-03, from https:// agupubs .onlinelibrary .wiley.com/doi/abs/10.1029/2011JC007301 doi: 10.1029/2011JC007301

Padman, L., Siegfried, M. R., \& Fricker, H. A. (2018, March). Ocean Tide Influences on the Antarctic and Greenland Ice Sheets. Reviews of Geophysics, 56(1), 142-184. Retrieved 2018-12-03, from https://agupubs .onlinelibrary.wiley .com/doi/abs/10.1002/2016RG000546 doi: 10.1002/2016RG000546

Parkinson, C. L. (2019, July). A 40-y record reveals gradual Antarctic sea ice increases followed by decreases at rates far exceeding the rates seen in the Arctic. Proceedings of the National Academy of Sciences, 116(29), 14414-14423. Retrieved 2019-09-11, from https://www. pnas .org/content/116/29/14414 doi: $10.1073 /$ pnas. 1906556116

Pritchard, H. D., Ligtenberg, S. R. M., Fricker, H. A., Vaughan, D. G., van den Broeke, M. R., \& Padman, L. (2012, April). Antarctic ice-sheet loss driven by basal melting of ice shelves. Nature, 484 (7395), 502-505. Retrieved 2018-1203, from http://www.nature.com/doifinder/10.1038/nature10968 doi: 10.1038/nature10968

Reese, R., Gudmundsson, G. H., Levermann, A., \& Winkelmann, R. (2018, January). The far reach of ice-shelf thinning in Antarctica. Nature Climate Change, 8(1), 53-57. Retrieved 2018-12-03, from http://www.nature.com/ articles/s41558-017-0020-x doi: 10.1038/s41558-017-0020-x

Richter, O. (2020). Post- and preprocessing tools for the roms whole antarctic ocean model. Zenodo. doi: 10.5281/ZENODO.3738998

Richter, O., Gwyther, D. E., Galton-Fenzi, B. K., \& Naughten, K. A. jun). The whole antarctic ocean model (WAOM v1.0): Development and evaluation. Geoscientific Model Development Discussion. (in review) doi: 10.5194/gmd-2020-164

Rignot, E., Jacobs, S. S., Mouginot, J., \& Scheuchl, B. (2013, July). Ice-Shelf Melting Around Antarctica. Science, 341(6143), 266-270. Retrieved 2018-1120, from http://science.sciencemag.org/content/341/6143/266 doi: 10 $.1126 /$ science. 1235798

Schodlok, M. P., Menemenlis, D., \& Rignot, E. ～(2016, February). Ice shelf basal melt rates around Antarctica from simulations and observations. Journal of Geophysical Research: Oceans, 121(2), 1085-1109. Retrieved 2018-1203, from https://agupubs . onlinelibrary.wiley.com/doi/abs/10.1002/ 2015JC011117 doi: 10.1002/2015JC011117

Stern, A. A., Dinniman, M. S., Zagorodnov, V., Tyler, S. W., \& Holland, D. M. (2013). Intrusion of warm surface water beneath the McMurdo Ice Shelf, Antarctica. Journal of Geophysical Research: Oceans, 118(12), 7036-7048. Retrieved 2019-02-03, from https://agupubs .onlinelibrary.wiley.com/ doi/abs/10.1002/2013JC008842 doi: 10.1002/2013JC008842

Stewart, A. L., Klocker, A., \& Menemenlis, D. (2018, January). Circum-Antarctic Shoreward Heat Transport Derived From an Eddy- and Tide-Resolving Simulation. Geophysical Research Letters, 45(2), 834-845. Retrieved 2018-1203, from https://agupubs.onlinelibrary.wiley.com/doi/abs/10.1002/ 2017GL075677 doi: 10.1002/2017GL075677 
Stewart, C. L., Christoffersen, P., Nicholls, K. W., Williams, M. J. M., \& Dowdeswell, J. A. (2019, April). Basal melting of Ross Ice Shelf from solar heat absorption in an ice-front polynya. Nature Geoscience, 1 . Retrieved 2019-05-09, from https://www .nature.com/articles/s41561-019-0356-0

Sverdrup, H. U. (1954, January). The Currents off the Coast of Queen Maud Land. Norsk Geografisk Tidsskrift - Norwegian Journal of Geography, 14(1-4), 239-249. Retrieved 2019-05-10, from https://doi.org/10.1080/ 00291955308542731 doi: 10.1080/00291955308542731

Timmermann, R., Wang, Q., \& Hellmer, H. H. (2012). Ice shelf basal melting in a global finite-element sea ice/ice shelf/ocean model. Annals of Glaciology, 53. Retrieved 2018-12-03, from http://www.igsoc.org/annals/53/60/ t60A156.html doi: 10.3189/2012AoG60A156

Wåhlin, A. K., Steiger, N., Darelius, E., Assmann, K. M., Glessmer, M. S., Ha, H. K., .. Viboud, S. $\quad(2020$, feb). Ice front blocking of ocean heat transport to an antarctic ice shelf. $\quad$ Nature, 578(7796), 568-571. doi: 10.1038/s41586-020-2014-5

Zhou, Q., Hattermann, T., Nøst, O. A., Biuw, M., Kovacs, K. M., \& Lydersen, C. (2014, June). Wind-driven spreading of fresh surface water beneath ice shelves in the Eastern Weddell Sea. Journal of Geophysical Research: Oceans, 119(6), 3818-3833. Retrieved 2019-01-18, from https:// agupubs.onlinelibrary.wiley.com/doi/abs/10.1002/2013JC009556 doi: 10.1002/2013JC009556 